\title{
An Analysis of Basic Accounting Practices of Microenterprises
}

\author{
Noor Aslinda Abu Seman, Nur Aniza Quantaniah Jusoh, Umi Kartini Rashid, Ahmad Kaseri \\ Ramin
}

\begin{abstract}
Every microenterprise needs to learn and perform basic accounting practices to ensure that their business progress is running smoothly. Besides able to improve the business performance of a company, accounting practices also represent the result of operations of a company, as well as the statement of financial position. Therefore, by understanding financial performance very well might help the microenterprises not only to evaluate and monitor their business activities but also facilitate them in a critical way to make a better decision. The purpose of this paper is to study the application of basic accounting practices among the microenterprises in Batu Pahat. The data were collected among 157 owners of microenterprises. The data were analysed in frequency and percentage form by using The Statistical Package for Social Sciences (SPSS). The findings showed that most of the microenterprises practiced a very basic accounting system, maintained both cash and accrual accounting and practiced recording both electronically and manually. The survey also showed that most of the microenterprises completed the accounting cycle by keeping records of their daily business transaction and prepared the financial statement at the end of period mostly on income statement and statement of cash flow. With such well-maintained and completed financial records, it can be translated into feasible and good decision-making which may eventually result in business success. Besides, this survey found that the main challenges that were faced by microenterprises were lack of accounting knowledge and limited cost and time in preparing the financial statement for their businesses. Thus, it was recommended that microenterprises should improve their accounting skills and increase their knowledge by joining any training for seminar on the accounting practices toward the effectiveness of their financial management and entrepreneurial development.
\end{abstract}

Keywords: Microenterprises, accounting practices, financial statement.

\section{INTRODUCTION}

Micro enterprises which are formed by the companies with the lowest characteristics among the Small and Medium Enterprises (SMEs) are now playing important role to contribute economic growth and poverty execution [1]. Microenterprise as a form of entrepreneurship had been characterized as one of the major forces for job creation,

Revised Manuscript Received on April 19, 2019.

Noor Aslinda Abu Seman, Department of Business Management, Faculty of Technology Management and Business, Universiti Tun Hussein Onn Malaysia, 86400 Batu Pahat, Johor.

Nur Aniza Quantaniah Jusoh, Department of Business Management, Faculty of Technology Management and Business, Universiti Tun Hussein Onn Malaysia, 86400 Batu Pahat, Johor.

Umi Kartini Rashid, Department of Business Management, Faculty of Technology Management and Business, Universiti Tun Hussein Onn Malaysia, 86400 Batu Pahat, Johor.

Ahmad Kaseri Ramin, Department of Business Management, Faculty of Technology Management and Business, Universiti Tun Hussein Onn Malaysia, 86400 Batu Pahat, Johor. further contributed to the economic growth [2], and their contribution was mainly depended on their performance [3]. But, numerous studies have revealed that the failure of small business such as microenterprises were mainly caused from inadequate entrepreneurial skills [4-6]. One of the most important entrepreneurial skill that can help microenterprise business operation to become a successful is accounting practices [7-11]. According to SMEinfo [12], accounting practices are vital important to the SMEs in making a better financial and management decision. They also help to prepare on annual taxes payment and furthermore, help to plan for the next step in the businesses [12]. According to Uddin et al. [13], accounting system is used to manage, monitor and control the income, expenses, and other financial activities of a business, including to prepare for the taxation purpose as well as supporting the organizational functions. Furthermore, it also useful to measure the financial performance of the company [14].

In other cases, Mbroh and Attom [15] observed that businesses that are keen in determining their profitability ought to include appropriate accounting principles, concepts, principles and standards to ensure the consistency of measurement. Additionally, accounting records can help to improve business performance and as confirmed by Abdul-Rahamon and Adejare [16], there is a strong positive relationship between accounting records keeping and growth of SMEs. In short, the SMEs will not be able to realize their businesses' condition if they fail to maintain proper books of accounts [17]. Zotorvie [18] also supported this notion that an inefficient use of inaccurate accounting information to support SME owners' financial decisions can affect the financial status and long-term sustainability of SMEs businesses. However, despite of its vital importance, SMEs' owners failed to apply the accounting practices in their businesses due to several issues. According to Dawuda and Azeko [19], high costs in the involvement of qualified personnel make it very difficult for SMEs owners to maintain proper book accounts. In fact, they also failed to uphold proper account books to avoid tax payments [19]. They assumed that the overall impact of poor financial record keeping is that the owners who provide strong financial statements could prevent them from conducting financial analysis to establish trends to find out whether their business is working properly or not. They are also unable to understand and foresee the business environment, and this is one of the indicators of business failure.

Naturally, the main aim of conducting a business is to

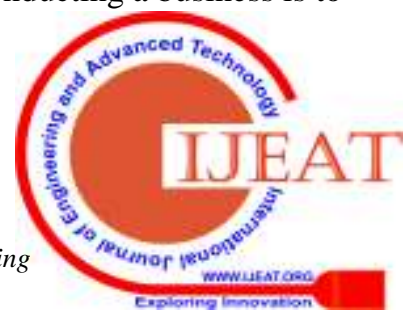


gain profit. However, many studies agreed that emphasis had to be given to those who have at least three years of business experience because three years of business experience is sufficient to assess an entrepreneur [20, 21]. Furthermore, Ferreira, Azevedo, and Ortiz [22] suggested that youngest firms; minimum three years, have the tendency to grow more than older ones. Despite that, many start-ups failed within three years of formation due to bad financial control and lack of correct accounting [12]. In addition, SMEinfo [12] further elaborated that it is crucial for the business owners to have an adequate record of business transactions; to keep track whether their businesses are gaining profit or deficit. Not only have that, but the basic accounting information also certify the dependability of their business financial reporting [12]. From the above argument, it is clear that many enterprises pursued the single entry accounting system as a record keeping tool for the tractability of its practice and for warranting productivity [23]. However, differ from beforehand, the microenterprises neglect on the financial planning, control, analysis and appraisal that led to the high failure rate of their businesses [24].

This paper seeks to examine the basic accounting practices among microenterprises because they stand the risk of hitting cash flow crisis, wasting money, and losing opportunities to expand their businesses [25]. Even though financial information can be used to measure performance, growth, financial position and the impact of improper decisions [26], the failure of a proprietary company may be associated with inadequate accounting records [27].

\section{LITERATURE REVIEW}

\section{Definition of Accounting Practices}

The Dictionary for Accounting terms [28], defines accounting practices as normal practical applications of accounting and/or auditing practices that occurs within a business. A firm's accounting practice refers to the method by which its accounting policies are implemented and adhered to on a routine basis [29]. It is the day to day implementation of the accounting policies of an organization [30], the system of procedures and controls that an accounting department uses to create and record business transactions. Accounting practice should ideally be extremely consistent, since there are a large number of business transactions that must be dealt with in exactly the same manner in order to produce consistently reliable financial statements [29]. It exists as the daily recording of financial data that is important to the evaluation and monitoring of the firm's economic activities [31].

\section{Definition of Microenterprises}

It has been found that the majority of business enterprises are categorized in the microenterprise group. Kushnir [32] explained that microenterprises are the lowest form of enterprises in terms of size that could be measured by either investment or employment or total assets of the firm. It was further explained that microenterprise also have the flexibility of easy start and exit. Bruhn and McKenzie [33] posited that the majority of the microenterprises in most countries remain as an informal entity. Microenterprises are usually small in size, however, they are responsive and capable of taking benefit of positions which larger enterprises are unable to embark on successfully [34]. Omar, Arokiasamy \& Ismail [35] state that in Malaysia, the definition for small medium enterprise (SMEs) are solely based on a fixed quantitative measure based on the total number of workers and the business sales turnover. The National SME Development Council stipulated that effective from 1 January 2014, in Malaysia, microenterprises are characterized as an organization with a total of less than 5 employees or total sales turnover of less than RM 300,000 and subject to all sectors of agriculture, mining and quarrying, construction, services and manufacturing [36]. An establishment must meet the requirement of either one of the two specified criteria, whichever is lower, to be considered as an SME.

A survey of the Department of Statistics Malaysia [37] found that, 98.5 percent of the total business establishments in Malaysia are SMEs. From the 907,065 SMEs, 76.5 percent of the business establishment are micro business whilst 21.2 percent of the business establishments are small businesses and the remaining are the medium enterprises [37]. The existence of microenterprises in every country is considered very important because of their ability to contribute to the enhancement of the social economy, to increase income-generating jobs, to explore new entrepreneurial talent, to develop marginalized areas, to improve the standard of living of the community, to create conditions for sustainable living and eliminating extreme poverty [38].

\section{The Application of Accounting Practices among Microenterprises}

Mitchell et al. [39] argued that SMEs short-term problems in areas such as costing, expenditure and cash flow could be help by providing accounting information to support monitoring and control. The age of business, size of the business, and the nature of the industry influenced the extent of accounting practices in SMEs [40]. Maseko and Manyani [14] contended that micro and small business record keeping is the backbone of one's business. Whilst, Muteti et al. [41] observed in their study that most enterprises kept several importance accounting records in their business including purchases records, sales records and expenses records. Furthermore, remembering the nature of financial transaction, keeping track of enterprises profits, for profit analysis purposes, to enable observing of the performance or improvement of their company and as a reference point in the growth of the enterprise were reasons cited for keeping records by the enterprises. The study also found that four important factors in the SMEs accounting systems were maintaining records for costing of goods and services, recording expenses and payments, recording sales and recording purchases. Muteti et al. [41] found that entrepreneurs were noted to keep records in order to remember, observe progress and track profit. Whereas, Germain [42] posited that SMEs perceive record keeping as 
a method of recovering initial investment in the form of cash at the end of the accounting period. However, if SME's accounting records are not maintained properly, long term sustainability of the business could be affected.

The study of Roslan et al. [43] found that small businesses daily transaction were recorded manually, some owners do not know the differences between revenue and net profit and majority of them did not maintain any financial reports for the business. Umeji and Obi [44] stated that recording and reporting daily business transactions by using accounting techniques helps owners to identify cash flow, cost of production, assets and liabilities. Whereas, according to Onaolapo and Adegbite [45], most SMEs do not comply with the double entry system of record keeping. It was posited by Abdul-Rahamon \& Adejare [16] that the double entry system is important in creating a convenient relationship which permits an interim check of accuracy of recording work at any time during the process.

Tanwongsval and Pinvanichkul [46] found in their study that SMEs have two major reasons in preparing financial statements which is (1) for the purpose of tax return, and (2) to measure their business's profitability. In addition, Lalin and Sabir [47] added that the most powerful pressure that forces SMEs to provide a complete financial statements is pressure coming from regulatory authorities. There is positive link between values of accounting data used inside SME with their business's outcome and continued existence [48], thus, resulted that most businesses had to close down due to failure to provide good accounting records and practices.

\section{The Importance of Accounting Practices}

One of the most important accounting practices needed by a business consists of keeping accurate records about how the business is doing financially over time. Muteti et al. [41] posited that it is important for business's operations and owner managers to adopt use of accounting practices and systems because it promotes effectiveness to prepare recording business transactions systematically and more proper which helping business preparing more accurate financial reports. Madurapperuma et al. [49] contended that proper record keeping ensures long term sustainability of the business and anticipates long term prospects whilst Okoli [23] argued that adequate record keeping will help the proprietors to keep track of the performance of their enterprises. Record keeping is a fundamental skill a business owner must have as the accounting information is vital for decision making even though preparing financial reports is not mandatory for small businesses and they have no obligation to keep proper books of accounts. However, Amaoko [50] maintained that proper accounting is paramount in any business and crucial in tracking all aspects of the business from the information contained in the books.

Maseko and Manyani [14] stated that record keeping and generation of financial report is at the heart of business activities and decision making. It was asserted by Sanga et al. [51] that keeping business records is an important driver for the success of a business and they observed that a comprehensive record or bookkeeping system enables business owners to develop accurate and timely financial reports that detail the progress and prospects of the business.
By having a good book of accounts can allow several businesses specially micro businesses to maintain precise accounting information which also help them in making decision [50, 52]. As contended by Owusu et al. [53], bookkeeping practices is a mechanical and systematic process of capturing economic consequence of business transactions in compliance with accepted Accounting Standards. Bookkeeping practices serves as the basis for proper planning and management of business activities [16, 50] and allows managers and owners to determine whether they are making profits or loss [53]. Abdul-Rahamon \& Adejare [16] argued that the general objectives of bookkeeping include improving efficiency and productivity, to control creation and growth to reduce operating costs, to ensue regulatory requirement. Mutua [54] argued that proper bookkeeping helps SMEs to control the activities and to help manage cost and expenses, whereas, according to Eric and Gabriel [55] bookkeeping enable managers to know the financial positions of their businesses and to take certain control measures to improve corporate performance.

\section{Challenges of Application of Accounting Practices}

Sibanda and Manda [56] defined challenges in accounting practices as the gaps, interruptions, or obstacles in implementing the accounting practices. The interruption of accounting principles, policies and systems during the process of recording and posting of business's transactions also is included in the context of challenges in accounting. They further stipulated that most research identifies causes which collectively represent accounting or financial problems and bad management as "internal" factors (the factors that are unique to the companies concerned). Enterprises confront various obstacles in adopting accounting practices since it is considered as to be time consuming, difficult to maintain, requires technical knowledge and reveals the enterprise to the taxpayer. However, the scope of the challenge is not limited to cash flow alone, but the right way of using the right set of skills, the application of efficient accounting systems and the lack of real business information is also part of the business accounting challenge [23].

The majority of micro business do not fully used their accounting information because lacking business knowledge and accounting skills. This is proved by several studies that due to these main reasons, numerous micro businesses could not prepared and practiced comprehensive records of account $[15,41,50,56-59]$ and the cost to hire professional and qualified accountants [15, 50]. It was indicated by Musah [57] that absence of specific guidelines for bookkeeping and accounting recordkeeping, fear of discouragement in case of a loss, inadequate education and training skills, and cost and time constraints are some of the challenges faced by SMEs. Maseko and Manyani [14] argued that several large SMEs' business that possess a specified degree of accounting skill and practical feasibility was seemly maximum utilized of accounting information, but this situation is rare for small businesses.

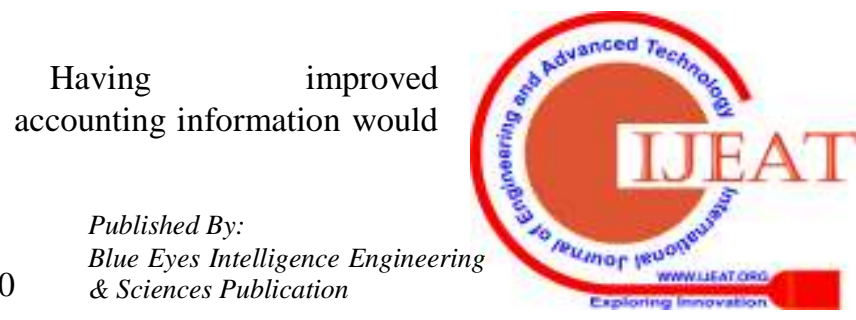


permit SME owners to manage their firms better and would allow them to access finance more easily. The lack of expertise as accounting functions do not only require knowledge of generally-accepted accounting rules or the tax regulation, but also require that one knows how to apply the rules in a given business environment [59]. Due to this Amaoko [50] found that most businesses which do not adopt proper accounting practices would cause difficulty in tracking the daily transaction of business and so difficult to identify the expenses and profits of the business at the end of the operation. A study by McMahon [60] found that most financial reporting practices made by SMEs does not meet the standards recommended and further claimed that the manager / owner of the SME seem most reluctant to submit financial reports for not accessible to outsiders whether by regulatory authorities or directly. Amaoko [50] discovered that the majority of SMEs failed to maintain a complete accounting record because they thought it was not necessary to keep accounting records and to disclose their financial position. Muteti et al. [41] explained that most enterprises do not provide and prepare proper accounting records as one way to not disclose their financial position to taxpayers and competitors. Whilst Mutambanengwe [58] noted that SMEs assumes that the practice of maintaining such accounting records is such a waste of time, money and effort as well as doing various ways of eliminating the records of transactions made by the owner in the event of any sudden investigation of any government agency. Osuala [61] posited that many enterprises record their transactions randomly without adherence to any established systems of accounting; hence making it difficult in keeping track of the cash flows in the enterprises.

\section{METHODOLOGY}

This study used quantitative methods and data collected through a questionnaire where the forms were distributed to the respondents to investigate the implementation of basic accounting practices among microenterprises. The target population for this study were microenterprises came from variety of business industry located in Batu Pahat, Johor. Years of operation were not considered in defining the subjects (micro-enterprise) of the study. A non-probability with convenience sampling technique was used in this study because it more suitable for researcher for approachability and nearness with respondents [62]. A total of 157 usable owners of microenterprises had been participated. The data were analyzed using Statistical Package for Social Science (SPSS) version 21 for descriptive analysis such as frequency and percentage.

\section{RESULTS AND DISCUSSION}

\section{Demographic Information of Microenterprises}

This section demonstrated and accordingly explains results on microenterprises' demographic characteristics, accounting basis used and accounting practices. Table 1 demonstrates that most $(56.1 \%)$ microenterprises are operated by male compared to female. This finding is similar with the survey by Vodă \& Florea [63] which showed that male entrepreneurs were more likely to start a business compared to female entrepreneurs. This fact is also supported by current small business trends and statistics in 2019 that indicated about $78 \%$ of male entrepreneurs had dominated the small business, while the remaining $22 \%$ was female entrepreneurs [64].

The majority $(31.2 \%)$ of owner of microenterprises were aged between 31-40 years old. This is similar with the finding by Chrysostome [65], Tengeh [66], and Fatoki and Patswawairi [67] which indicated that small business are mainly owned by middle-aged entrepreneurs. Middle-aged entrepreneurs are better than young one because they have enough experiences, skills, and knowledge which lead them to become more successful [68]. The next age group with a significant percentage were the ages ranging between 41-50 years old $(27.4 \%)$ and $20-30$ years old $(26.8 \%)$. Yaacob and Azmi [69] found that entrepreneurs aged 41-60 years were more successful since they had coped with life's challenges, and more experienced in handling the business. There is slightly different number of percentage for entrepreneurs aged 20-30 years old. However, this number can indicated that many young people now interested to start entrepreneurship and hereby can reduced the unemployment rate in country.

In term of education level, $34.4 \%$ of respondents completed secondary education level, $28.7 \%$ having achieved a diploma certificate, $18.5 \%$ with a bachelor's degree, $10.8 \%$ matric or equivalent to matric certificate, and respondents with a master's degree, primary education, and no formal education constituted of $2.5 \%$ each. This results is in line with the findings by Sibanda and Manda [56] that most of owners did not accomplished a university qualification which recommends that owners were less qualified, thus required them to acquire accounting knowledge and skills in order to employ the required accounting practices in their business. From the business background, the findings showed that $8.9 \%, 47.1 \%, 25.5 \%$ and $18.5 \%$ of the owners were in business for less than 1 year, between 1 to 5 years, between 6 to 10 years and more than 10 years respectively. Overall, it can be seen that most of $50 \%$ respondents involved in the business for less than 5 years which indicating that they were still beginners in handling business operation. Majority $(24.2 \%)$ of owners of microenterprises came from hardware business, $20.4 \%$ grocery business, $17.8 \%$ clothing and pharmacy business, $10.2 \%$ others business, and $9.6 \%$ electrical business. It can be concluded that majority microenterprises involved in the study comes from the hardware business.

Table 1: Demographic Information of Microenterprises

\begin{tabular}{|c|c|c|c|}
\hline Variables & Category & Frequency & $\begin{array}{l}\text { Percent } \\
\text { age }(\%)\end{array}$ \\
\hline \multirow{2}{*}{ Gender } & Male & 88 & 56.1 \\
\hline & Female & 69 & 43.9 \\
\hline \multirow{5}{*}{ Age } & Below 20 years & 2 & 1.3 \\
\hline & $20-30$ years & 42 & 26.8 \\
\hline & $31-40$ years & 49 & 31.2 \\
\hline & $41-50$ years & 43 & 27.4 \\
\hline & $\begin{array}{l}60 \text { years and } \\
\text { above }\end{array}$ & 21 & 13.4 \\
\hline
\end{tabular}




\begin{tabular}{|c|c|c|c|}
\hline \multirow{4}{*}{ Ethnicity } & Malay & 71 & 45.2 \\
\hline & Chinese & 75 & 47.8 \\
\hline & Indian & 8 & 5.1 \\
\hline & Others & 3 & 1.9 \\
\hline \multirow{3}{*}{ Marital status } & Married & 113 & 72.0 \\
\hline & Single & 43 & 27.4 \\
\hline & Divorce & 1 & 0.6 \\
\hline \multirow{7}{*}{$\begin{array}{l}\text { Education } \\
\text { level }\end{array}$} & $\begin{array}{l}\text { No formal } \\
\text { education }\end{array}$ & 4 & 2.5 \\
\hline & $\begin{array}{l}\text { Primary } \\
\text { education }\end{array}$ & 4 & 2.5 \\
\hline & $\begin{array}{l}\text { Secondary } \\
\text { education }\end{array}$ & 54 & 34.4 \\
\hline & $\begin{array}{l}\text { Certificate/Matr } \\
\text { ic }\end{array}$ & 17 & 10.8 \\
\hline & Diploma & 45 & 28.7 \\
\hline & $\begin{array}{l}\text { Bachelor's } \\
\text { Degree }\end{array}$ & 29 & 18.5 \\
\hline & Master's Degree & 4 & 2.5 \\
\hline \multirow{4}{*}{$\begin{array}{l}\text { Number } \\
\text { years } \\
\text { business }\end{array}$} & Less than 1 year & 14 & 8.9 \\
\hline & $1-5$ years & 74 & 47.1 \\
\hline & $6-10$ years & 40 & 25.5 \\
\hline & $\begin{array}{l}\text { More than } 10 \\
\text { years }\end{array}$ & 29 & 18.5 \\
\hline \multirow{6}{*}{$\begin{array}{l}\text { Type } \\
\text { business }\end{array}$} & Clothing & 28 & 17.8 \\
\hline & Grocery & 32 & 20.4 \\
\hline & Hardware & 38 & 24.2 \\
\hline & Electrical & 15 & 9.6 \\
\hline & Pharmacy & 28 & 17.8 \\
\hline & Others & 16 & 10.2 \\
\hline
\end{tabular}

Accounting Basis, Method and Purpose

From the survey, Table 2 shows that $49 \%$ of microenterprises most prefer both cash and accrual or credit as their accounting basis, while only $5.1 \%$ use the accrual or credit and the remaining $45.9 \%$ use cash accounting basis for their business. According to Zarandia et al. [70], the cash accounting basis was one of popular methods for small businesses, while accrual accounting basis was generally used by large companies. The findings of this study explained that majority of owners used both of accounting basis depend on situation and based on several reasons such as for tax purposes, involved credit transaction and for obtaining credit. Besides, this study also showed part of the respondents also preferred cash method only for their accounting basis. This is basically indicated that the accounting records kept are limited to cash receipts and payments journals which can minimise bad debt and directly make their business to be more sustainable.

The table also illustrates that the majority (51.6\%) of owners used both a manual and an electronic method to record their business transaction; 29.3\% captured their transactions manually and $19.1 \%$ used an electronic bookkeeping system. It can been seen that most of the microenterprises that chose cash and both accounting basis used both electronic and manual bookkeeping system to record their transaction. As said by Pinson [71], business can used both a manual and electronic bookkeeping method concurrently to record business transactions to make the bookkeeping practices more effective and efficient. Conversely, several owners still used manual bookkeeping system because it facilitate them to record transactions besides more cheaper compared to electronic bookkeeping system [71, 72]. A small number of owners were found to use only electronic bookkeeping system for capturing their business transaction. Altogether, around $70 \%$ of owners utilised electronic bookkeeping system. This indicated that there is increasing numbers of microenterprises in preferring computerized bookkeeping as it paper less and minimise data entry mistake $[73,74]$.

In Table 3, questions pertaining the reasons of chosen for the above accounting basis which gives flexibility for the respondents to choose more than one answers. The majority $63.7 \%$ of the owners adopted the preferred accounting basis for cash flow management, followed by $52.2 \%$ wanted to avoid bad debts, while $36.9 \%$ adopted for the purpose of inventory management. In addition, another $31.2 \%$ used the accounting basis because of having reliable supplier, $22.9 \%$ did so because they have no regular customer, $17.8 \%$ did so because they lack knowledge on how to assess credit worthiness of a customer, and a few of $13.4 \%$ adopted for the purpose of providing for their credit sales. This findings revealed that cash flow management, avoid bad debts, inventory management, having reliable supplier, and offering credit sales were the main reasons why microenterprises were using both cash and accrual methods or solely accrual method for accounting basis. This findings is similar with the findings by [56]. While, not having regular customer and lack of knowledge on how to assess credit worthiness of a customer's reasons suits the cash basis method.

Table 2: Accounting Basis and Accounting Bookkeeping Method

\begin{tabular}{|l|l|l|l|l|}
\hline $\begin{array}{c}\text { Accounting } \\
\text { bookkeeping } \\
\text { method/ } \\
\begin{array}{c}\text { Accounting } \\
\text { basis }\end{array}\end{array}$ & $\begin{array}{c}\text { Electron } \\
\text { ic }\end{array}$ & $\begin{array}{c}\text { Manua } \\
\mathbf{l}\end{array}$ & Both & Total \\
\hline Cash & 9 & 34 & 29 & $\begin{array}{l}72 \\
(45.9 \%)\end{array}$ \\
\hline $\begin{array}{l}\text { Accrual } \\
\text { Credit }\end{array}$ & 4 & 1 & 3 & $8(5.1 \%)$ \\
\hline Both & 17 & 11 & 49 & $\begin{array}{l}77 \\
(49.0 \%)\end{array}$ \\
\hline Total & 30 & $\begin{array}{l}46 \\
(29.3 \%\end{array}$ & $\begin{array}{l}81 \\
(51.6 \%\end{array}$ & $\begin{array}{l}157 \\
(100.0 \%)\end{array}$ \\
\hline
\end{tabular}

Table 3: Reasons Choose Accounting Basis

\begin{tabular}{|l|c|c|}
\hline \multicolumn{1}{|c|}{ Reason } & Frequency & Percent \\
\hline No regular customers & 36 & 22.9 \\
\hline $\begin{array}{l}\text { Lack of knowledge on } \\
\text { how to assess credit } \\
\text { worthiness of customer }\end{array}$ & 28 & 17.8 \\
\hline Offer credit sales & 21 & 13.4 \\
\hline To avoid bad debts & 82 & 52.2 \\
\hline Having reliable suppliers & 49 & 31.2 \\
\hline $\begin{array}{l}\text { For inventory } \\
\text { managements flow }\end{array}$ & 100 & 36.9 \\
\hline $\begin{array}{l}\text { For cash } \\
\text { management }\end{array}$ & 63.7 \\
\hline
\end{tabular}




\section{Basic Accounting Practices by Microenterprises}

Next, the question pertaining accounting records that usually performed by microenterprises as showed in Fig. 1. It revealed that majority $(58.0 \%)$ of microenterprises practice a cash book for their accounting records, followed by $50.3 \%$ of microenterprises keep record their transaction using a day books, $37.6 \%$ did record in a ledger account, $29.9 \%$ used personal jotter or notes, $21.0 \%$ did perform asset registers, and the remaining $2.5 \%$ did not practice any accounting records. This findings indicated that most of microenterprises keep the cash book and keep sales record using day books were more interested in their expenditure and sales information compared to other records. They might think these records are enough for them in recording the business transaction. Besides, the findings also revealed that majority of owners did keep business accounting records, but did do not maintained all the required books of original entry, does cannot provide sufficient information to prepare financial report. This is because they may lack of accounting knowledge and their ability to hire professional accountants.

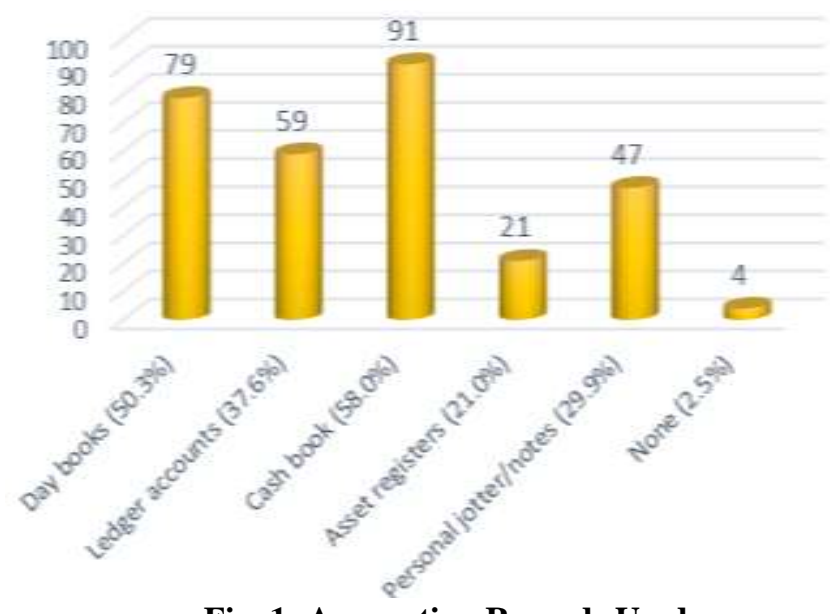

Fig. 1: Accounting Records Used

Table 4 shows the tabulation for basic information about recording practice implemented by microenterprises. On the subject of how owners determine their profit margin, $74.5 \%$ of the owners indicated that they determine their profit by deducting their cost price from their selling price and $25.5 \%$ does it by randomly. On the question of keeping record, majority $(90.4 \%)$ of owners often keeping record for their business, while the remaining $9.6 \%$ did not maintain the keeping practice. An additional, the findings revealed that $41.4 \%, 33.8 \%$ and $17.2 \%$ did update their accounting records on a daily, weekly, and monthly basis respectively. Only $7.6 \%$ of owners did update their records every two weeks. On the question on who does the recoding, $99 \%$ of owners do the recording themselves and the remaining $28.7 \%$ and $8.3 \%$ have personnel that takes up the recordings and outsourcing respectively. Further, the findings showed that most $(88.5 \%)$ of microenterprises did prepare business' account at the end of the period. Only small entities of $11.5 \%$ did not implement the practice. Additionally, the business' account is principally prepared by owners himself $(59.2 \%)$, while the outstanding of $32.5 \%$ and $8.3 \%$ are prepared by employee and outsourcing respectively.
Overall, it can be seen that majority of owners have basic knowledge to calculate their profit margin as they often keeping basic accounting records such as cash book, day books, and ledger books based on daily basis or weekly basis. There is important to complete either on a daily, weekly or monthly basis of accounting records because it enable a small business' owners to precisely evaluate the business's financial position [75]. The findings also indicated that owners did both the recording and preparing the business' account at the end of period instead appointing another person to perform that.

Table 4: Basic Information on Recording Practice Implemented by Microenterprises

\begin{tabular}{|c|c|c|c|}
\hline Practice & Category & Frequency & $\begin{array}{l}\text { Percentage } \\
(\%)\end{array}$ \\
\hline \multirow[t]{2}{*}{$\begin{array}{l}\text { Determining } \\
\text { profit margin }\end{array}$} & $\begin{array}{lr}\text { Selling } & \text { price } \\
\text { minus } & \text { cost } \\
\text { price } & \\
\end{array}$ & 117 & 74.5 \\
\hline & By randomly & 40 & 25.5 \\
\hline \multirow{2}{*}{$\begin{array}{l}\text { Frequency of } \\
\text { keeping record }\end{array}$} & Yes & 142 & 90.4 \\
\hline & No & 15 & 9.6 \\
\hline \multirow{4}{*}{$\begin{array}{l}\text { Frequency of } \\
\text { updating } \\
\text { record }\end{array}$} & Daily & 65 & 41.4 \\
\hline & Weekly & 53 & 33.8 \\
\hline & $\begin{array}{ll}\text { Every } & \text { two } \\
\text { weeks }\end{array}$ & 12 & 7.6 \\
\hline & Monthly & 27 & 17.2 \\
\hline \multirow[b]{3}{*}{$\begin{array}{l}\text { Person in } \\
\text { charge for } \\
\text { bookkeeping }\end{array}$} & Owners & 99 & 63.1 \\
\hline & $\begin{array}{l}\text { Employee e.g. } \\
\text { account clerk }\end{array}$ & 45 & 28.7 \\
\hline & $\begin{array}{l}\text { Outsourcing } \\
\text { e.g. } \\
\text { professional } \\
\text { individual } \\
\text { accountant }\end{array}$ & 13 & 8.3 \\
\hline \multirow{2}{*}{$\begin{array}{ll}\text { Status of } \\
\text { account } \\
\text { preparation }\end{array}$} & Yes & 139 & 88.5 \\
\hline & No & 18 & 11.5 \\
\hline \multirow{3}{*}{$\begin{array}{l}\text { Person in } \\
\text { charge for } \\
\text { account } \\
\text { preparation }\end{array}$} & Owners & 93 & 59.2 \\
\hline & $\begin{array}{l}\text { Employee e.g. } \\
\text { account clerk }\end{array}$ & 51 & 32.5 \\
\hline & $\begin{array}{l}\text { Outsourcing } \\
\text { e.g. } \\
\text { professional } \\
\text { individual } \\
\text { accountant }\end{array}$ & 13 & 8.3 \\
\hline
\end{tabular}

Types and Purpose for Preparation Financial Statement

Fig. 2 illustrates that microenterprises are commonly prepared statement of cash flow $(63.7 \%)$, comprehensive income statement or known as profit and loss statement (58.0\%), balance sheet $(42.7 \%)$, whereas $5.7 \%$ did not keep any form of financial statement. Majority of microenterprises prepared statement of cash flow. It is important to prepare statement of cash flow because is very necessary to the sustainable of a business specifically small business [76]. Moreover, some of microenterprises also published comprehensive income statement to facilitate the business to understand their net income which may beneficial in decision making process. Some of them also prepared balance sheet to help them understand the financial health of a business whether their assets can cover all the 
liabilities of business. In total, this study found microenterprises do completed of financial statement for their business. But some of them also prepared solely certain financial statement for their own interest.

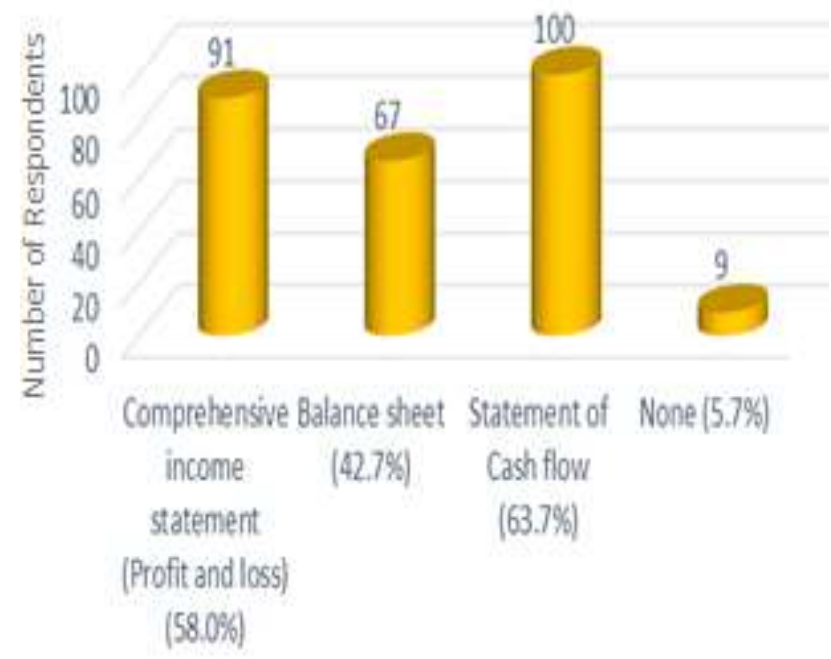

Fig. 2: Preparation of Financial Statements

On the subject of purpose of preparing the account as presented in Fig. 3, the major reason is to determine business' profitability (84.1\%). It followed for tax purposes $(52.2 \%)$, for obtaining loans from financial institution (23.6\%). While limited numbers of owners prepared their account for chartered accounting firm (19.7\%) and as a statuary obligation $(19.1 \%)$. The results indicated that determine business' profitability, tax purposes, and obtaining loans from financial institution were the main reasons why microenterprises prepared those financial statements as mentioned previously. Santos, Pires, and financial statement particularly balance sheet and income statement for the purpose of decision making process, evaluate the financial impact, to maintain the existing management, help in investment decision and conform with tax obligations.

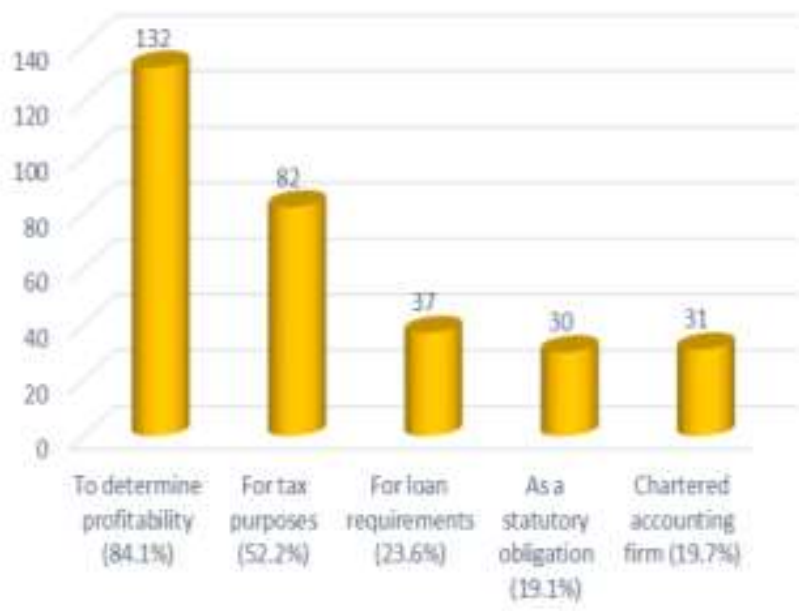

Fig. 3: Reason of Preparing Financial Statements

Challenges during Preparing Accounting for Business

Further, the question regarding the main challenges that was faced by microenterprises during preparing accounting for business. Fig. 4 shows that $36.9 \%$ of the respondents lacked accounting knowledge, $32.5 \%$ faced cost constraints, Fernandes [77] claimed that it is important to prepare

and $12.1 \%$ who were unable to separate business from private issues. The other challenges included $11.5 \%$ and $7.0 \%$ who were lacked guiding accounting rules and unable to complete accounting record. Part of the total of 157 respondents had attained some form of training in basic bookkeeping and accounting procedures [78]. The remaining 79 respondents had no training at all. Thus, this findings is not surprisingly if the respondents claimed lacked accounting knowledge became a major challenges to them. Small business frequently lacked the essential accounting skills because preparing accounting for business required both of basic accounting and the knowledge to perform the systems in operating the business [78]. According to Nicholas [79], outsourcing may assist the companies to prepare complete accounting business and avoid the costs related with adopting new technologies and training employees. However, the appointment of outsourcing companies also requires a high cost. Thus, the cost constraints became second major reason of challenges that was faced by microenterprises because it interconnected to each other.

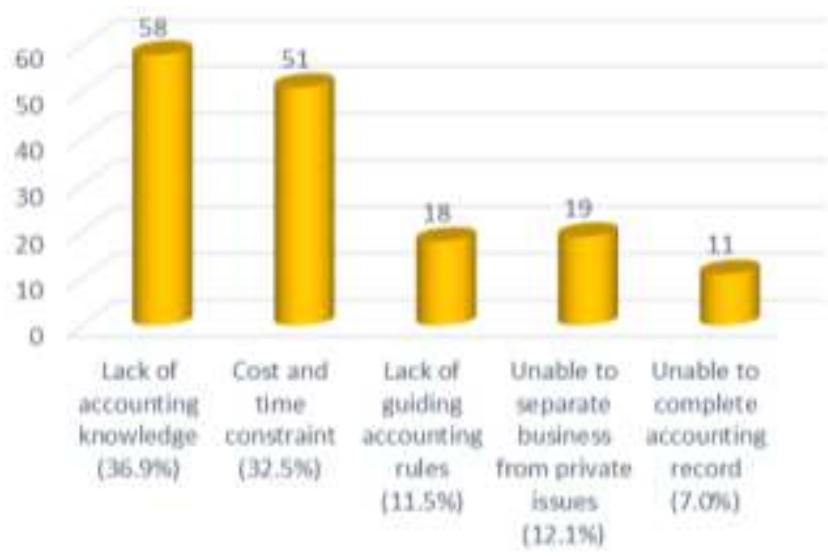

Fig. 4: Challenges Faced by Microenterprises

\section{CONCLUSION AND RECOMMENDATION}

The study aimed at finding out the basic accounting practices of microenterprises across different types of business such as clothing, grocery, electrical, hardware and pharmacy. From the findings, it can be concluded that most microenterprises utilise both cash and accrual accounting basis and used both manual and electronic bookkeeping system. The main reasons of choosing both of cash and accrual method are cash flow management, avoid bad debts, and inventory management. In addition, it is noted that most of microenterprises are very concern on the recording of cash book and sales book which related to their expenses and sales of daily business. The results further showed that microenterprises do completed the accounting cycle by keeping recorâns of their business transaction daily and prepared the fingancial statement at the end of period mostly on income statement, statement of cash flow and balance sheet. These owner itself pather than staff or outsourcing companies.

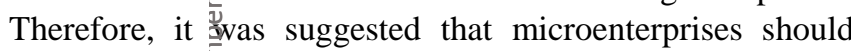
also involve inș comprehensive bookkeeping practices

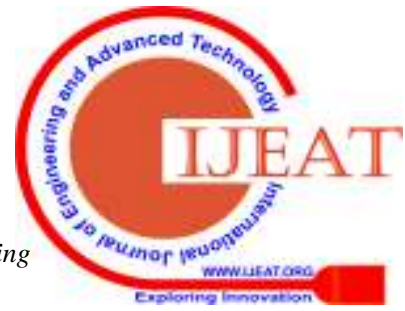


including cash book, sales book, ledger, and journal in order to generate the accurate reflection of the business' financial performance. With such maintaining and completing financial records, it can be translated into the feasible and good decision-making which may eventually result in business success bookkeeping records are maintained. Among the main reasons for accounting preparation are to determine business profitability and comply with tax obligation. This study also found that the main challenges that were faced by microenterprises were lack of accounting knowledge and limited cost and time constraint through preparing the accounting for their business. Thus, in order to avoid business' failure, it was recommended that microenterprises should improve their accounting skills and increase their knowledge by joining any training or seminar for accounting practices toward the effectiveness to the financial management and entrepreneurial development.

\section{ACKNOWLEDGMENT}

The authors would like to extend their gratitude to Universiti Tun Hussein Onn Malaysia for financial support. All those who contributed direct or indirectly are thanked.

\section{REFERENCES}

1. Nyathi, M. and O.H. Benedict, An Analysis of Bookkeeping Practises of Micro-Entrepreneurs in the Retail Clothing Industry in Cape Town, South Africa. Journal of Entrepreneurship \& Organization Management, 2017. 6(2): p. 1-8.

2. Fuad, N., \& Bohari, A.M., Malay women entrepreneurs in the small and medium sized ICT-related business: A study on need for achievement. International Journal of Business and Social Science, 2011. 2(13): p. 272-278.

3. Azmi, I.A.G., Basir, S.A., Che Hashim, R., \& Al-Banna, M.H. , Challenges of muslim women entrepreneurs in Malaysian SMEs. International Journal of Innovation, Management and Technology, 2014. 5(6): p. 428-233.

4. Arasti, Z., Zandi, F., Bahmani, N. , Business failure factors in Iranian SMEs: Do successful and unsuccessful entrepreneurs have different viewpoints? Journal of Global Entrepreneurship Research, 2014. 4: p. 1-14.

5. Aziz, K., Accounting information system satisfaction and job satisfaction among Malaysian accountants. Paper Presented at the 7th Pacific Asia, 2003.

6. Baumann, M.R., Bonner, B.L. , An Expectancy theory approach to group coordination: Expertise, task features, and member behavior. Journal of Behavioral Decision Making, 2017. 30: p. 407-419.

7. Rajaram, R. and C. O'Neill, Profit or No Profit-Does the SME Sector Really Know? Themes in Management and Informatics, 2009. 16: p. 99-119.

8. Brigham, E. and M. Ehrhardt, Financial management: theory \& practice. 2013: Cengage Learning.

9. Drexler, A., Fischer, G., Schoar, A. , Keeping it simple: Financial literacy and rules of thumb. American Economic Journal: Applied Economics, 2014. 6: p. 1-31.

10. Gaskill, L.R., H.E. Van Auken, and H.S. Kim, Impact of operational planning on small business retail performance. Journal of Small Business Strategy 2015. 5: p. 21-36.

11. Höglund, H. and D. Sundvik, Financial reporting quality and outsourcing of accounting tasks: Evidence from small private firms. Advances in Accounting, 2016. 35 : p. 125-134.

12. SMEinfo. Bookkeeping: Anticipate your accounting cycle. April 2019 [cited 7 SRC - BaiduScholar;
Available from: http://www.smeinfo.com.my/managingyour-finance-of-your-business/bookkeping-anticipateyour-accounting-cycle.

13. Uddin, R., et al., Accounting practices of small and medium enterprises in Rangpur, Bangladesh. Journal of Business and Financial Affairs. 2017. 6(4 ): p. 1-8.

14. Maseko, N. and O. Manyani, Accounting practices of SMEs in Zimbabwe: An investigative study of record keeping for performance measurement (A case study of Bindura). Journal of Accounting and Taxation, 2011. 3: p. 171-181.

15. .Mbroh, J.K. and E.B. Attom, Accounting and control systems practiced by small and micro enterprise owners within the Cape Coast Metropolitan Area of Ghana. Asian Journal of Business and Management Sciences, 2011. 1(9): p. 28-47.

16. Abdul-Rahamon, O.A., A.T. Adejare, and I. Sciences, The analysis of the impact of accounting records keeping on the performance of the small scale enterprises. International Journal of Academic Research in Business and Social, 2014. 4(1 ): p. 2222-6990.

17. Ademola, G.O., O.J. Samuel, and O. Ifedolapo, The roles of record keeping in the survival and growth of small scale enterprises in Ijumu Local Government Area of Kogi State. Global Journal of Management and Business Research, 2017. 12(13): p. 29-39.

18. .Zotorvie, J.S.T., A study of financial accounting practices of small and medium scale enterprises (SMEs) in Ho Municipality, Ghana. International Journal of Academic Research in Business and Social Sciences, 2017. 7(7): p. 29-39.

19. Dawuda, A. and I. Azeko, An Assessment of Financial Records Keeping Behaviour of Small Scale Businesses in Ghana: Study of Bolgatanga Municipality. International Journal of Finance and Accounting, 2015. 4(3 ): p. 187194.

20. Aziz, S.A. and R. Mahmood, The relationship between business model and performance of manufacturing small and medium enterprises in Malaysia. African Journal of Business Management, 2011. 5(22): p. 8918-8932.

21. Ekpe, I., Women entrepreneur and economic development in Nigeria: Characteristics for success. International Journal of Business and Social Science, 2011. 2(1): p. 287-291.

22. Ferreira, J.J., S.G. Azevedo, and R.F. Ortiz, Contribution of resource-based view and entrepreneurial orientation on small firm growth. Cuadernos de Gestin 2011. 11(1): p. $95-116$.

23. Okoli, B.E., Evaluation of accounting systems used by small scale enterprises in Nigeria: The case of EnuguSouth East Nigeria. Asian Journal of Business and Management, 2011. 3 p. 235-240.

24. Fatoki, O., An Investigation into the financial management practices of new Micro-Enterprises in South Africa. Journal of Social Science, 2012. 33: p. 179-188.

25. Dodor, C.T., T.C. Adade, and T.K. Daniel, Evaluation of the effects of sound bookkeeping practices on the growth of small and medium-scale enterprises (SMEs) in Ho Municipality, Ghana. . EPRA International Journal of Research and Development, 2017. 2(9): p. 42-51.

26. Bwana, K.M. and J. Mwakujonga, The practice of preparing and using financial information in financial decisions: A survey of SMEs in Tanzania. European Journal of Business and Management, 2013. 5(9): p. 161-169.

27. Peacock, R.W., Small business bankruptcy. Accounting Forum, 2008. 1(3 ): p. 51-52. 
28. Shim, J.K. and J.G. Siegel, Dictionary of accounting terms. 2010, NY: Barron's: Hauppauge.29. Accountingtools.com. Accounting Practice definition. 2019 [cited 7 SRC - BaiduScholar; Available from: https://www.accountingtools.com/articles/accountingpractice-definition-and-usage.html.

29. Businessdictionary.com. Accounting Practice definition. 2019 [cited 7 SRC - BaiduScholar; Available from: http://www.businessdictionary.com/definition/accounting -practice.html.

30. Investopedia.com., Accounting Practice. Retrieved on April from httpswwwinvestopediacomtermsaaccountingpracticeasp, 2019. 7 SRC - BaiduScholar

31. Kushnir, K. How Do Economies Define Micro, Small and Medium Enterprises (MSMEs)?. Companion Note for the MSME Country Indicators. 2019; Available from: http://www.ifc.org/wps/wcm/connect/624b8f804a17abc5 b4acfddd29332b51/MSME-CI

32. Bruhn, M. and D. McKenzie, Entry regulation and the formalization of microenterprises in developing countries. The World Bank Research Observer, 2014. 29(2): p. 186-201.

33. Malaysia, B.N., Economic and Financial Developments in Malaysia Economic and Financial Developments in Malaysia in the Second Quarter OF 2015. 2015.

34. Omar, S.S., L. Arokiasamy, and M. Ismail, The Background and Challenges Faced by the Small Medium Enterprises. Resource Development Perspective International Journal of Business and Management, 2009. 4(10): p. 95-102.

35. Corp., S. Small and Medium Enterprises (SMEs) definition. 2019 [cited 7 SRC - BaiduScholar; 2015-12]. Available from: http://www.smecorp.gov.my/index.php/en/policies/-2109-09-49/sme-definition.

36. Malaysia, D.o.S., Economic Census 2016: Profile of SMEs. 2016.

37. Ladzani, V.M. and J.J. Van Vurren, Entrepreneurship Training For Emerging SMEs In South Africa. Journal of Small Business Management, 2002. 40(2 ): p. 151-161.

38. Mitchell, F., G. Reid, and J. Smith, Information system development in the small firm: The use of management accounting. 2000, United Kingdom: CIMA Publishing.

39. Holmes, S. and D. Nicholls, Modeling the accounting information requirements of small businesses. Vol. 19. 1989. 143-150.

40. Muteti, N., M. Namusonge, and D. Nzomo, Accounting Enterprise Development in Makueni County, Kenya. Open Journal of Accounting, 2018. 7 p. 181-190.

41. Germain, P.J. Top 10 Small business book keeping tips. 2019; Available from: http://ezinearticles.com.

42. Roslan, N., et al., Preliminary Investigation: Accounting Literacy among Small Business Owners. International Journal of Academic Research in Business and Social Sciences, 2018. 8(10): p. 32-47.

43. Umeji, A.U. and C.A. Obi, Cost Accounting Skills Needs of Small Business Operators. American Journal of Industrial and Business Management, 2014. 4(5 ): p. 246257.

44. Onaolapo, A.A. and T.A. Adegbite, The analysis of the impact of accounting records keeping on the performance of the small scale enterprises. International Journal of Academic Research in Business Social Sciences, 2014. 4(1): p. 23-45.

45. Tanwongsval, V. and T. Pinvanichkul, Accounting Information Requirements and Reporting Practices of Thai SMEs. King Mongkut University Technology, 2008: p. $59-74$ Systems for Records Keeping Practices for Small

46. Lalin, H. and R.I. Sabir, Research on Usage and Usefulness Perception of Financial Accounting Practices in Less Developing Countries: A case of Cambodia. Proceedings of the Proceedings of the 7th International Conference on Innovation Management, 2010: p. 18811885.

47. Lybaert, N., The Information use in an SME: Its Importance and some Elements of Influence. Vol. 10. 1998. 171-191.

48. Madurapperuma, M.W., P.M.C. Thilakerathne, and I.N. Manawadu, Accounting Record Keeping Practices in Small and Medium Sized Enterprise's (SME's) in Sri Lanka. Journal of Finance and Accounting 2016. 4 (4): p. 188-193.

49. Amoako, G.K., Accounting Practices of SMEs: A Case Study of Kumasi Metropolis in Ghana. International Journal of Business and Management, 2013. 8(24 ): p. 73-83.

50. Sanga, D., J. Kasubi, and L. Kisumbe, A challenge of business record keeping for Tanzania small and medium enterprises: A case of Madukani Ward-Dodoma Region. European Journal of Business Management, 2014. 6(38 ): p. 2222-2839.

51. Biryabarema, E., Small Scale Business and Commercial Banks in Uganda. 1998, Kampala: Makerere University Press.

52. Owusu, E.E., E.N. Assabil, and S. Asare-Kyire, Assessing the impacts of proper book-keeping on the performance of small and medium scale enterprises (SMEs) in Kwaebibirem district of Ghana. The International Journal of Science Technoledge, 2015. 3(7 ): p. 84-91.

53. Mutua, J.M., Effect of bookkeeping on the growth of small and medium enterprises in Chuka town. European Journal of Business Social Sciences, 2015. 4(7): p. 102112.

54. Eric, E.O. and D. Gabriel, Challenges of book keeping on small and medium scale enterprises in Kwaebibirem district: The case of Appex global (Ghana) limited. International Journal of Business \& Management Cases, 2012. 1(2): p. 1-12.

55. Sibanda, J. and D. Manda, Symptoms of accounting practices that contribute to small business failures. Problems and Perspectives in Management 2016. 14(4) p. 4-1.

56. Musah, A., Benefits and Challenges of Bookkeeping and Accounting Practices of SMEs and Its Effect on Growth and Performance in Ghana. Journal of AccountingBusiness Management, 2017. 24(2 ): p. 1636.

57. Mutambanengwe, J., Zimbabwe: Obstacles to SME Success in the country. 2012, Harare: Financial Gazette

58. Everaert, P., G. Sarens, and J. Rommel, Outsourcing of Accounting Tasks in SMEs: An extended TCE Model, in Working Paper No. 2004/403, B. Universiteit Gent. Kuiperskaai, Editor. 2006

59. McMahon, R.G.P., Putting SME Financial Reporting into Theoretical and Practical Perspective, in Research Paper Series, A. The Flinder University of South Australia, Editor. 1999. p. 98-100.

60. Osuala, E.C., Principles and Practices of Small Business Management in Nigeria: A didactic approach. 1993, Nsukka: Fulladu Publishing Company.

61. Etikan, I., S. Musa, and R. Alkassim, Comparison of convenience sampling and purposive sampling. American Journal of Theoretical and Applied Statistics 2016. 5(1): p. 1-4 
62. Vodă, A. and N. Florea, Impact of personality traits and entrepreneurship education on entrepreneurial intentions of business and engineering students. Sustainability 2019. 11(4): p. 1-34.

63. Financial, G. Current Small Business Trends and Statistics. 2019; Available from: https://www.guidantfinancial.com/small-businesstrends/.

64. Chrysostome, E., The success factors of necessity immigrant entrepreneurs: In a search of a model. Thunderbird International Business Review 2010. 52: p. 137-152.

65. Tengeh, R.K., A business framework for the effective start-up and operation of African immigrant-owned businesses in the Cape Town Metropolitan area, South Africa, in Ph Cape Peninsula University of Technology. 2011.

66. Fatoki, O. and T. Patswawairi, The motivations and obstacles to immigrant entrepreneurship in South Africa. KamlaRaj, 2012. 32 p. 133-142.

67. Sawang, S. Why middle-aged entrepreneurs are better than young ones. The Conversation. 2019 [cited 2018 SRC - BaiduScholar; Available from: http://theconversation.com/why-middle-agedentrepreneurs-are-better-than-young-ones-96297.

68. Yaacob, Y. and I. Azmi, The relationship between demographic towards the achievement of a successful Muslim entrepreneur in Malaysia. Journal of Advanced Management Science, 2016. 4(1): p. 35-40.

69. Zarandia, H., et al., Accrual-based accounting system versus cash-based accounting: An empirical study in municipality organization. Management Science Letters, 2013. 3: p. 251-256.

70. Pinson, L., Keeping the books: basic record-keeping and accounting for the successful small business. 2007, United States of America: Kaplan Publishing.

71. Benedict, R.G., An investigation of the accounting records maintained by black businesses in rural Qwaqwa, in Accounting in the Faculty of Economic and financial sciences 2012, University of Johannesburg.

72. Alves, M.D.C., Information technology roles in accounting tasks-A multiple case study. International Journal of Trade, Economics and Finance, 2010. 1: p. 103-107.

73. Zakaria, W.Z.W., N. Ilias, and N. Wahab, A Survey on the Impact of Accounting Information System on Tasks Efficiency: Evidence from Malaysian Public Sector Agencies. International Review of Management and Marketing, 2017. 7: p. 183-190.

74. Henderson, K. Accounting Methods for Small Business 2019; Available from: https://smallbusiness.chron.com/accounting-methodssmall-business-4903.html.

75. Aren, A. and A. Sibindi, Cash flow management practices: An empirical study of small businesses operating in the South African retail sector. Risk governance \& control: financial markets \& institutions, 2014. 4(2): p. 87-100.

76. Santos, J., A. Pires, and P. Fernandes, The importance to financial information in the decision-making process in company's family structure. Contaduría y Administración, 2018. 63(1): p. 1-23.

77. Dorasamy, M., et al., Critical success factors in outsourcing of accounting functions in Malaysian small medium-sized enterprises (SMes). Kajian Malaysia, 2010. 28(2): p. 36-39.

78. Nicholas, C.B., Outsourcing: The definitive views, applications and implications. 2006, New Jersey: John Wiley \& Sons, Inc. 